\section{JURNAL EKONOMI EFEKTIF}

ISSN : $2622-8882$, E-ISSN : 2622-9935

Jurnal Ekonomi Efektif, Vol. 3, No. 3, April 2021

@Prodi Manajemen Fakultas Ekonomi Universitas

Pamulang

\title{
PENGARUH PIUTANG TERHADAP PEROLEHAN LABA PADA PT. SINAR MAS AGRO RESOURCES AND TECHNOLOGY, TBK
}

\author{
Neneng Khoiriah \\ Universitas Pamulang, Tangerang Selatan, Banten, Indonesia \\ dosen02456@unpam.ac.id
}

Manuskrip: Feb-2021 Ditinjau: Feb-2021; Diterima: Feb-2021; Online: Apr-2021; Diterbitkan: Apr-2021

\begin{abstract}
ABSTRAK
Penelitian ini bertujuan untuk mengetahui pengaruh piutang terhadap perolehan laba pada PT. Sinar Mas Agro Resources and Technology, Tbk. Metode yang digunakan adalah explanatory research. Teknik analisis menggunakan analisis statistik dengan pengujian regresi, korelasi, determinasi dan uji hipotesis. Hasil penelitian ini variabel Piutang diperoleh nilai ratarata sebesar 1.809,95. Variabel Perolehan laba diperoleh nilai rata-rata 2.025,05. Piutang berpengaruh positif dan signifikan terhadap Perolehan laba dengan nilai persamaan regresi Y $=877,915+0,634 \mathrm{X}$, dan nilai koefisien korelasi 0,750 atau memiliki tingkat hubungan yang kuat dengan nilai determinasi 56,2\%. Uji hipotesis diperoleh signifikansi $0,000<0,05$.
\end{abstract}

Kata Kunci: Piutang, Perolehan Laba.

\section{ABSTRACT}

This study aims to determine the effect of accounts receivable on earnings at PT. Sinar Mas Agro Resources and Technology, Tbk. The method used is explanatory research. The analysis technique uses statistical analysis with regression testing, correlation, determination and hypothesis testing. The results of this study, the Receivables variable obtained an average value of 1.809.95. The variable of profit acquisition obtained an average value of 2,025.05. Receivables have a positive and significant effect on earnings with the regression equation $Y$ $=877.915+0.634 X$, and a correlation coefficient value of 0.750 or have a strong level of relationship with a determination value of 56.2\%. Hypothesis testing obtained a significance of $0.000<0.05$.

Keywords: Accounts Receivable, Profit. 


\section{PENDAHULUAN}

\section{A. Latar Belakang Masalah}

Pada umumnya tujuan perusahaan melakukan kegiatan operasional adalah untuk memperoleh laba yang maksimum serta mencapai tujuan- tujuan perusahaan yang lainnya. Setiap perusahaan berusaha agar mencapai laba atau memperoleh keuntungan yang semaksimal mungkin. Dengan adanya laba yang cukup tinggi dan didukung oleh nilai perusahaan yang semakin baik maka kredibilitas dan kontinuitas perusahaan dapat dipertahankan serta perusahaan dapat terus tumbuh dan melakukan ekspansi dalam kegiatan bisnisnya.

Memasuki era globalisasi perekonomian dan perdagangan bebas menyebabkan semakin ketatnya persaingan usaha, khususnya di tanah air. Di berlakukannya MEA (Masyarakat Ekonomi Asean), membuat persaingan global semakin tidak terhindarkan. Setiap Negara di Asean di tuntut untuk membuka pasar domestiknya terhadap produk dan SDM dari Negara-negara lain. Hal ini akan berakibat masuknya pesaing-pesaing baru dari Negara lain yang memiliki kualitas dan hasil produksi relatif lebih baik. Sehingga persaingan yang ketat tentunya akan terjadi, tidak terkecuali di Indonesia.

Sejalan dengan hal tersebut, krisis ekonomi dan melemahnya nilai tukar Rupiah membuat perusahaan yang menghasilkan produk sejenis harus dapat bersaing dan menghasilkan profit/laba dari investasi yang telah dilakukan agar perusahaan dapat mempertahankan kelangsungan usahanya. Tingginya persaingan bisnis karena adannya faktor perkembangan perekonomian yang semakin pesat, membuat setiap perusahaan harus mampu mengembangkan inovasi, memperbaiki kinerja, dan membuat strategi khusus untuk dapat bersaing dengan perusahaan sejenis lainnya. Salah satu bentuk persaingan antar perusahaan sejenis yaitu bersaing mendapatkan pangsa pasar yang luas dipengaruhi oleh daya beli dari masyarakat. Strategi yang tepat antara lain dengan membuat kebijakan penjualan secara kredit.

Penjualan secara kredit merupakan salah satu upaya untuk bisa mengatasi persaingan dengan perusahaan sejenis lainnya karena penjualan kredit dapat menambah usaha. Masalah piutang dan penjualan secara kredit menjadi begitu penting dalam kaitannya dengan perusahaan, jika harus menentukan berapa jumlah piutang yang optimal. Di samping itu, pengelolaan piutang harus dengan efisien karena menyangkut tentang laba dan tambahan laba yang akan diperoleh karena perubahan kebijakan penjualan dengan beban yang timbul akibat dari adanya piutang. Perusahaan yang menerapkan penjualan secara kredit dapat menyebabkan penundaan pembayaran setelah beberapa lama barang yang telah diterima oleh pelanggan, hal ini berdampak makin besarnnya dana yang tertanam dalam piutang akibat pembayaran tertunda. Besarnya jumlah volume penjualan kredit setiap triwulan, periode atau tahunnya, berarti perusahaan harus dapat menyediakan penanaman investasi yang lebih besar lagi dalam piutang.

Penjualan kredit yang dilakukan oleh perusahaan biasanya akan membawa dampak resiko yaitu munculnya berbagai macam biaya, seperti halnya menambah pegawai yang mengurus dan mengawasi administrasi kredit, adanya bunga pinjaman terkait dengan piutang serta akan bertambahnya resiko berupa penjualan kredit yang tidak terbayar oleh pelanggan atau piutang yang tidak tertagih (bad dedt), sehingga biasanya mengurangi jumlah penjualan bersih perusahaan dari total besarnya piutang yang dimiliki. Mengatasi resiko tersebut sebelum memberikan kredit kepada pelanggan dengan melalui standar kredit yang menggambarkan kualitas minimum untuk dijadikan acuan pertimbangan penilaian pelanggan dengan system 5C yaitu karakter (character), Kemampuan (capacity), Modal (capital), Jaminan (collateral), Kondisi (conditions). Di 
samping formula $5 \mathrm{C}$ tersebut di dalam pemberian kredit perusahaan akan memperhatikan aspek-aspek pertimbangan kredit seperti aspek umum, aspek ekonomi/komersil, aspek teknik, aspek yuridis, aspek kemanfaatan dan kesempatan kerja, aspek terakhir yang harus di analisa yang merupakan aspek yang paling penting adalah aspek keuangan. Pengelolaan piutang tidak hanya analisa kredit yang perlu diperhatikan, persyaratan kredit dan kebijakan pengumpulan piutang sangat penting dalam mengendalikan piutang perusahaan. Persyaratan kredit merupakan kondisi pembayaran kredit yang diberikan kepada pelanggan dan kebijakan pengumpulan piutang merupakan salah satu prosedur yang meliputi waktu dan cara-cara penagihannya kepada pelanggan yang akan melakukan pembayarannya dengan tepat waktu.

Pengelolaan piutang yang efektif menunjukan perputaran piutang setiap tahun mengalami peningkatan dan pengumpulan piutang selalu tepat dengan target yang diharapkan perusahaan. Pengelolaan piutang yang efektif akan mempengaruhi peningkatan profitabilitas perusahaan, karena dalam upaya pengelolaan piutang yang efektif pada perusahaan akan menggambarkan tingkat profitabilitas. Hubungan dari pengelolaan piutang yang efektif dengan profitabilitas yaitu piutang yang efektif menggambarkan setiap perputaran piutang dalam periode semakin tinggi, sehingga perusahaan berpeluang mendapatkan keuntungan dari timbulnya perputaran piutang yang semakin cepat dan pada akhirnya mempengaruhi profitabilitas perusahaan. Profitabilitas menunjukan kemampuan perusahaan memperoleh laba dalam hubungannya dengan penjualan, total aktiva, maupun modal sendiri.

PT. Sinar Mas Agro Resources and Technology Tbk adalah salah satu perusahaan berbasis kelapa sawit terintegrasi. Aktivitas utama perseroan dimulai dari penanaman dan pemanenan sawit, pengolahan tandan buah segar (TBS) menjadi minyak kelapa sawit (CPO) dan inti sawit (PK), serta penyulingan CPO menjadi produk industri dan konsumen seperti minyak goreng, margarin dan shortening. Perusahaan melakukan penjualan sebagai salah satu aktivitas perusahaan. Penjualan perusahaan belakangan ini mengalami penurunan, hal ini tentu dapat menurunkan minat investor dan calon pembeli dari luar negeri untuk bertransaksi. Di samping itu, adanya kredit macet akibat dari kebijakan penjualan secara kredit semakin berdampak buruk bagi perusahaan. Hal ini menyebabkan menurunnya profit perusahaan.

Salah satu cara untuk dapat bersaing dengan perusahaan sejenis adalah dengan memperluas pangsa pasar. Artinya, perusahaan di tuntut untuk melakukan inovasi dalam hal cara penjualan kepada konsumen. Dengan memberikan kebijakan penjualan kredit kepada konsumen diharapkan akan menaikkan jumlah penjualan sehingga berpengaruh terhadap besarnya laba atau profit perusahaan. Penjualan yang bersifat kredit akan menimbulkan piutang. Dengan adanya piutang tersebut, penulis mencoba mengemukakan pengaruh piutang terhadap laba perusahaan. Menurut Purwanto (2012:12) secara kuantitatif, laba adalah selisih antara penerimaan-penerimaan bisnis dengan pengeluaran- pengeluaran bisnis.

Berdasarkan latar belakang permasalahan diatas, maka penulis tertarik untuk meneliti pengaruh piutang PT. Sinar Mas Agro Resources and Technology Tbk dan membahasnya dalam suatu skripsi yang diberi judul: "Analisis Piutang dan Pengaruhnya Terhadap Laba pada PT. Sinar Mas Agro Resources and Technology Tbk.”.

\section{B. Rumusan Masalah}

1. Bagaimana Piutang pada pada PT. Sinar Mas Agro Resources and Technology, Tbk?.

2. Bagaimana Perolehan laba pada PT. Sinar Mas Agro Resources and Technology, Tbk?. 
3. Adakah pengaruh antara Piutang terhadap Perolehan laba pada PT. Sinar Mas Agro Resources and Technology, Tbk?.

\section{Tujuan Penelitian}

1. Untuk mengetahui kondisi Piutang pada PT. Sinar Mas Agro Resources and Technology, Tbk.

2. Untuk mengetahui kondisi Perolehan laba pada PT. Sinar Mas Agro Resources and Technology, Tbk.

3. Untuk mengetahui pengaruh antara Piutang terhadap Perolehan laba pada PT. Sinar Mas Agro Resources and Technology, Tbk

\section{METODE PENELITIAN}

\section{Populasi}

Populasi dalam penelitian ini laporan keuangan PT. Sinar Mas Agro Resources and Technology, Tbk selama 10 tahun

2. Sampel

Teknik pengambilan sampling dalam penelitian ini adalah samplel jenuh, dimana semua anggota populasi dijadikan sebagai sampel. Dengan demikian sampel dalam penelitian ini laporan keuangan PT. Sinar Mas Agro Resources and Technology, Tbk selama 10 tahun.

\section{Jenis Penelitian}

Jenis penelitian yang dipakai adalah asosiatif, dimana tujuannya adalah untuk mengetahui mencari keterhubungan antara variabel independen terhadap variabel dependennya

\section{Metode Analisis Data}

Dalam menganalisis data digunakan uji validitas, uji reliabilitas, analisis regresi linier sederhana, koefisien korelasi, koefisien determinasi dan uji hipotesis.

\section{HASIL PENELITIAN DAN PEMBAHASAN}

\section{Analisis Deskriptif}

Pada pengujian ini digunakan untuk mengetahui skor minimum dan maksimum skor tertinggi, ratting score dan standar deviasi dari masing-masing variabel. Adapun hasilnya sebagai berikut:

Tabel 1. Hasil Analisis Descriptive Statistics

Descriptive Statistics

\begin{tabular}{lr|r|r|c|r} 
& N & Minimum & Maximum & Mean & \multicolumn{1}{c}{ Std. Deviation } \\
\hline Piutang (X) & 10 & 285.89 & 3328.48 & 1809.954 & 941.777 \\
\hline Perolehan laba (Y) & 10 & 617.08 & 3261.66 & 2025.052 & 795.920 \\
\hline Valid N (listwise) & 10 & & & & \\
\hline
\end{tabular}

Piutang diperoleh nilai minimum sebesar 282,89 dan nilai maximum 3328,48 dengan rata-rata sebesar 1.809,95 dengan standar deviasi 941,777. Perolehan laba diperoleh nilai minimum sebesar 617,08 dan nilai maximum 3261,95 dengan rata-rata sebesar 2.025,05 dengan standar deviasi 795,920.

\section{Analisis Verifikatif.}

Pada analisis ini dimaksudkan untuk mengetahui pengaruh variabel independen terhadap variabel dependen. Adapun hasil pengujian sebagai berikut: 


\section{a. Analisis Regresi Linier Sederhana}

Uji regresi ini dimaksudkan untuk mengetahui perubahan variabel dependen jika variabel independen mengalami perubahan. Adapun hasil pengujiannya sebagai berikut:

Tabel 2. Hasil Pengujian Regresi Linier Sederhana

\section{Coefficients $^{\text {a }}$}

Unstandardized

Coefficients

\begin{tabular}{l|r|r|r|r|r} 
Model & B & Std. Error & Beta & \multicolumn{1}{c}{ t } & \multicolumn{1}{c}{ Sig. } \\
\hline $1($ Constant $)$ & 877.915 & 398.962 & & 2.200 & .059 \\
\hline Piutang $(\mathrm{X})$ & .634 & .198 & .750 & 3.207 & .012 \\
\hline
\end{tabular}

Berdasarkan hasil pengujian pada tabel di atas, diperoleh persamaan regresi $\mathrm{Y}$

$=877,915+0,634 \mathrm{X}$. Dari persamaan tersebut dijelaskan sebagai berikut:

1) Konstanta sebesar 877,915 diartikan jika Piutang tidak ada, maka telah terdapat nilai Perolehan laba sebesar 877,915 point.

2) Koefisien regresi Piutang sebesar 0,634, angka ini positif artinya setiap ada peningkatan Piutang sebesar 0,634 point maka Perolehan laba juga akan mengalami peningkatan sebesar 0,634 point

\section{b. Analisis Koefisien Korelasi}

Analisis koefisien korelasi dimaksudkan untuk mengetahui tingkt kekuatan hubungan dari variabel independen terhadap variabel dependen baik secara parsial maupun simultan. Adapun hasil pengujian sebagai berikut:

Tabel 3. Hasil Pengujian Koefisien Korelasi Piutang Terhadap Perolehan laba.

\section{Correlations $^{\text {b }}$}

\begin{tabular}{llr|r} 
& & Perolehan laba \\
& & Piutang (X1) & \multicolumn{2}{c}{ (Y) } \\
\hline Piutang (X) & Pearson Correlation & 1 & $.750^{*}$ \\
\cline { 2 - 4 } & Sig. (2-tailed) & & .012 \\
\hline Perolehan laba (Y) & Pearson Correlation & $.750^{*}$ & 1 \\
\cline { 2 - 4 } & Sig. (2-tailed) & .012 & \\
\hline
\end{tabular}

Berdasarkan hasil pengujian diperoleh nilai korelasi sebesar 0,750 artinya Piutang memiliki hubungan yang kuat terhadap Perolehan laba.

\section{c. Analisis Koefisien Determinasi}

Analisis koefisien determinasi dimaksudkan untuk mengetahui besarnya persentase pengaruh dari variabel independen terhadap variabel dependen. Adapun hasil pengujian sebagai berikut:

Tabel 4. Hasil Pengujian Koefisien Determinasi Piutang Terhadap Perolehan laba.

Model Summary

\begin{tabular}{|c|c|c|c|c|}
\hline Model & $\mathrm{R}$ & R Square & $\begin{array}{l}\text { Adjusted R } \\
\text { Square }\end{array}$ & $\begin{array}{l}\text { Std. Error of the } \\
\text { Estimate }\end{array}$ \\
\hline 1 & $.750^{a}$ & .562 & .508 & 4498 \\
\hline
\end{tabular}

Berdasarkan hasil pengujian diperoleh nilai determinasi sebesar 0,562 artinya

Piutang memiliki kontribusi pengaruh sebesar 56,2\% terhadap Perolehan laba.

\section{d. Uji Hipotesis}

Pengujian hipotesis dengan uji t digunakan untuk mengetahui hipotesis mana yang diterima. Rumusan hipotesis: Terdapat pengaruh yang signifikan antara Piutang 
terhadap Perolehan laba.

Tabel 5. Hasil Uji Hipotesis Piutang Terhadap Perolehan laba.

\section{Coefficients $^{a}$}

Unstandardized

Coefficients

\begin{tabular}{|c|c|c|c|c|c|}
\hline Model & B & Std. Error & Beta & $\mathrm{t}$ & Sig. \\
\hline 1 (Constant) & 877.915 & 398.962 & & 2.200 & .059 \\
\hline Piutang (X) & .634 & .198 & .750 & 3.207 & .012 \\
\hline
\end{tabular}

Berdasarkan hasil pengujian pada tabel di atas, diperoleh nilai t hitung $>\mathrm{t}$ tabel atau $(3,207>2,306)$, dengan demikian hipotesis yang diajukan bahwa terdapat pengaruh yang signifikan atara Piutang terhadap Perolehan laba diterima.

\section{PEMBAHASAN PENELITIAN}

\section{Kondisi Jawaban Responden Variabel Piutang}

Berdasarkan data empiris dan analisis data, variabel Piutang diperoleh nilai ratarata per tahun sebesar 1.809,95.

\section{Kondisi Jawaban Responden Variabel Perolehan laba}

Berdasarkan data empiris dan analisis data, variabel Perolehan laba diperoleh nilai rata-rata per tahun sebesar 2.025,05.

\section{Pengaruh Motivasi Terhadap Kinerja Karyawan}

Piutang berpengaruh signifikan terhadap Perolehan laba dengan persamaan regresi $\mathrm{Y}=877,915+0,634 \mathrm{X}$, nilai korelasi sebesar 0,750 atau memiliki hubungan yang kuat dengan kontribusi pengaruh sebesar 56,2\%. Pengujian hipotesis diperoleh nilai $t$ hitung $>\mathrm{t}$ tabel atau $(3,207>2,306)$. Dengan demikian hipotesis yang diajukan bahwa terdapat berpengaruh signifikan antara Piutang terhadap Perolehan laba diterima.

\section{V.PENUTUP}

\section{Kesimpulan}

a. Tingkat piutang perusahaan selama kurun waktu tahun 2010-2019 menhalami perkembangan yang fluktuatif dengan rata-rata perolehan sebesar 1.809,95 trilyun.

b. Tingkat pencapaian laba perusahaan selama kurun waktu tahun 2010-2019 menhalami perkembangan yang fluktuatif dengan rata-rata perolehan sebesar 2.025,05 trilyun.

c. Piutang berpengaruh signifikan terhadap Perolehan laba dengan persamaan regresi $\mathrm{Y}$ $=877,915+0,634 \mathrm{X}$, nilai korelasi sebesar 0,750 atau kuat dan kontribusi pengaruh sebesar 56,2\% sedangkan sisanya sebesar 57,9\% dipengaruhi faktor lain. Uji hipotesis diperoleh nilai t hitung $>\mathrm{t}$ tabel atau $(3,207>2,306)$.

\section{Saran}

a. Melakukan evaluasi terhadap kebijakan piutang yang diambil perseroan, termasuk melakukan peramalan (forecasting) yang mendalam tentang kondisi perekonomian dan politik di Indonesia masa mendatang sehingga dapat memperkecil dampak ketidakpastian ekonomi dan politik terhadap tingkat perputaran piutang dan laba perseroan.

b. Melakukan re-scheduling, yaitu menjadwal ulang kontrak piutang yang sudah jatuh tempo dengan maksud memberikan keringanan penambahan jangka waktu terhadap konsumen atau perusahaan lain agar dapat melunasi hutangnya. 
c. Melakukan komunikasi yang terus-menerus kepada konsumen atau perusahaan lain yang memiliki hutang, sehingga pengawasan terhadap piutang perseroan dapat dijalankan dengan baik.

d. Mengalokasikan sebagian kecil dari pendapatan dan laba yang diperoleh sebagai cadangan penghapusan piutang, agar perseroan dapat segera melakukan penghapusan (write off) piutang-piutang yang tidak tertagih karena berbagai faktor sehingga tingkat kerugian dapat di kurangi.

\section{DAFTAR PUSTAKA}

Aditya, Bagus. 2015. Pengelolaan Piutang yang Efektif Sebagai Upaya Meningkatkan Profitabilitas (studi kasus pada perusahaan CV Walet Sumber Barokah Malang periode 2012-2014). Malang: Jurnal. Universitas Brawijaya Malang.

Agus Harjito \& Martono, (2010) "Manajemen Keuangan" Yogyakarta: Penerbit Ekonisia. Agus Sartono. (2010). "Manajemen Keuangan Toeri dan Aplikasi”, Edisi keempat, Yogyakarta: Penerbit BPFE.

Algifari. (2015). “Analisis Regresi untuk Bisnis dan Ekonomi”. Yogyakarta: BPFE.

Amelia, R. W., \& Sunarsi, D. (2020). Pengaruh Return On Asset Dan Return On Equity Terhadap Debt To Equity Ratio Pada PT. Kalbe Farma, TBK. Ad-Deenar: Jurnal Ekonomi dan Bisnis Islam, 4(01), 105-114.

Arikunto, Suharsimi (2014). "Prosedur Penelitian Suatu Pendekatan Praktek". Jakarta: Rineka Cipta.

Atmajaya, Lukas Setia. 2008. Teori dan Praktik Manajemen Keuangan. Yogyakarta: CV.Andi.

Bambang Riyanto, (2011). "Dasar-dasar Pembelanjaan Perusahaan". Edisi ke empat, BPFE Yogyakarta.

Dendawijaya, Lukman. 2005. Manajemen Perbankan edisi Kedua. Bogor: Ghalia Indonesia.

Fahmi, Irham (2012), "Pengantar Manajemen Keuangan" Cetakan pertama. Bandung: Penerbit Alfabeta.

Gunawan, Ade. 2013. Pengaruh Rasio Keuangan Terhadap Pertumbuhan Laba pada Perusahaan Perdagangan di Indonesia. Medan: Jurnal. Universitas Muhammadiyah Sumatera Utara.

Hanafi, Mamduh M dan Abdul Halim. 2008. Analisis Laporan Keuangan. Edisi Ketiga. Jakarta: ISBN.

Handriyani, Febri. 2016. Pengaruh Perputaran Piutang Terhadap Kas Pada PT. Total Logistik Center. Tangerang Selatan: Skripsi. Universitas Pamulang.

Haque, M. G., Nurjaya, N.,Affandi, A., Erlangga, H., \& Sunarsi, D. (2021). Micro Financial Sharia Non-bank Strategic Analysis: a Study at BMT Beringharjo, Yogyakarta. Budapest International Research and Critics Institute (BIRCI-Journal): Humanities and Social Sciences, 4(2), 1677-1686.

Husnan Suad \& Pudjiastuti, Enny. 2008. Dasar-Dasar Manajemen Keuangan. Yogyakarta: UPP AMP YKPM.

Ikatan Akuntan Indonesia. 2009. Standard Akuntansi Keuangan. Jakarta: Salemba Empat. Imam Ghozali (2017). "Aplikasi Analisis Multivariate Dengan Program SPSS”. Edisi Kelima. Semarang: Badan Penerbit Undip.

Indriyo \& Basri. 2007. Standart Akuntansi Indonesia. Jakarta: Salemba Empat.

Jasmani, J. (2018). Pengaruh Kinerja Keuangan Terhadap Harga Saham (Analisis Pada Perusahaan Property dan Real Estate Yang Go Public di Bursa Efek Indonesia. Jurnal Akuntansi Indonesia, 12(2). 
Jasmani, J. (2019). The Effect of Liquidity and Working Capital Turnover on Profitability at PT. Sumber Cipta Multiniaga, South Jakarta. PINISI Discretion Review, 3(1), 2938.

Kasmir, (2010). "Pengantar Manajemen Keuangan”, Edisi Pertama, Cetakan kedua, Jakarta: Penerbit Prenada Media.

Keown, Scott, Martin \& Petty. 2009. Dasar-Dasar Manajemen Keuangan. Jakarta: PT. Gramedia Pustaka Utama.

Martono dan Agus Harjito, (2011). "Manajemen Keuangan”, Jakarta: Penerbit Ekonisia.

Munawir (2010), "Analisis Laporan Keuangan”, Edisi Ke Empat, Penerbit Liberty, Yogyakarta.

Nofiana, L., \& Sunarsi, D. (2020). The Influence of Inventory Round Ratio and Activities Round Ratio of Profitability (ROI). JASa (Jurnal Akuntansi, Audit dan Sistem Informasi Akuntansi), 4(1), 95-103.

Nurjannah. 2012. Analisis Tingkat Perputaran Piutang pada PT. Adira Finance Makassar. Makassar: Skripsi. Universitas Hasanuddin Makassar.

Pujiati, H., Sunarsi, D., Affandi, A., \& Anggraeni, N. (2021). Effect of ISO 9001: 2015 Quality Management Implementation in Education on School Performance. Journal of Contemporary Issues in Business and Government, 27(1), 1848-1855

Purwanto, D.R. Iwan. 2012. Pengantar Bisnis. Tangerang Selatan: Modul. Universitas Pamulang.

Santoso, Singgih (2015). "Menguasai Statistik Multivariat". Jakarta: PT Elex Media Komputindo.

Sartono, "Manajemen Keuangan Aplikasi Dan Teori", Edisi Keempat, BPFE, Yogyakarta, 2008.

Sawir, Agnes. 2005. Analisis Kinerja Keuangan dan Perencanaan Keuangan Perusahaan. Cetakan Kelima. Jakarta: PT. Gramedia Pustaka.

Sugiyarso, G. dan F. Winarni, "Manajemen Keuangan (Pemahaman Laporan Keuangan, Pengelolaan Aktiva, Kewajiban dan Modal serta Pengukuran

Sugiyono (2017), "Metode Penelitian Administrasi : dilengkapi dengan Metode R \& D". Bandung: Alfabeta.

Suhartono, A., Jati, W., \& Sunarsi, D. (2019). Pengaruh Earning Per Share Dan Return On Asset Terhadap Harga Saham Pada PT. Bank Negara Indonesia Tbk Periode 20092018. Jurnal Manajemen, Bisnis dan Organisasi (JUMBO), 3(3), 182-194.

Sutrisno. 2008. Manajemen Keuangan. Jakarta: PT. Rajawali Press.

Syahyunan. 2008. Manajemen Keuangan I (Perencanaan, Analisis dan Pengendalian Keuangan). Cetakan Pertama. Medan: USU Press.

Syamsudin, Lukman. 2009. Manajemen Keuangan Perusahaan. Jakarta: Raja Grafindo Persada.

Tresmayanti, Eka. 2013. Pengaruh Perputaran Piutang Terhadap aliran Kas pada PT. Sinar Mas Agro Resources and Technology Tbk periode 2008-2012. Tangerang Selatan: Skripsi. Universitas Pamulang.

Wahyuni, Fitri. 2013. Pengaruh Rasio Keuangan Terhadap Pertumbuhan Laba pada Perusahaan Perdagangan di Indonesia. Medan: Jurnal. Universitas Muhammadiyah Sumatera Utara.

Weston, J. Fred. 2007. Manajemen Keuangan. Edisi Kesebelas. Jakarta: Binarupa Aksara. 